\title{
Biomechanics of the Human Canine Pillar Based on its Geometry Using Finite Element Analysis
}

\author{
Biomecánica del Pilar Canino en el Cráneo Humano Basada \\ en la Geometría Utilizando Análisis de Elementos Finitos
}

\author{
Alexandre Rodrigues Freire*; Felippe Bevilacqua Prado*; Ana Cláudia Rossi"; \\ Pedro Yoshito Noritomi***; Francisco Haiter Neto**** \& Paulo Henrique Ferreira Caria ${ }^{*}$
}

FREIRE, A. R.; PRADO, F. B.; ROSSI, A. C.; NORITOMI, P. Y.; NETO, F. H. \& CARIA, P. H. F. Biomechanics of the human canine pillar based on its geometry using finite element analysis. Int. J. Morphol., 32(1):214-220, 2014.

SUMMARY: This study evaluated the stress distribution based on the canine pillar geometry in human skull, using a finite element analysis. Computed tomography of human skull was used to build a finite element model, which was composed by all bony structures of canine pillar: canine eminence, canine fossa, frontal process of maxilla, glabellum and superciliary arch. A support on the bite contact of maxillary canine tooth and a resultant force of the masticatory muscles was applied in the simulation. Equivalent Von-mises and maximum principal stresses were analyzed along the structures that compose the canine pillar geometry. Von-mises stress presented high stress concentrated at the canine fossa and frontal process of maxilla. Maximum principal stress showed compression areas at the canine fossa and part of frontal process and tensile stress at canine eminence and part of the frontal process. In conclusion, the different stress areas means different force concentrations transmitted along the canine pillar geometry during a peak canine bite.

KEY WORDS: Skull; Biomechanics; Finite element analysis.

\section{INTRODUCTION}

Facial skeleton is considered an ideal structure to resist masticatory forces, which structure is constituted, basically by three pillars (Sorní et al., 2005; Hillowalla \& Kanth, 2007).

Skull pillars are rigid structures, which are strategically distributed around the different craniofacial cavities (orbits, nasal and oral cavities and paranasal sinuses) (Hylander et al., 1991). The important region of bite from anterior teeth, mainly the canine tooth, is supported by canine or anterior pillar, which is localized at anterior region of the skull. Based on the bone constitution and geometry of canine pillar (CP), the force dissipates from canine bite to the alveolar process, at the canine eminence region, toward the glabellum and superciliary arch involving the canine fossa and frontal process of maxilla (Hillowalla \& Kanth; Wroe et al., 2010).
Functional morphology of skull pillars has been related to the force dissipation and stress distribution in the skull, as well as the bony response to stresses both functional chewing (Fanuscu \& Caputo, 2004; Caroena et al., 2010; Lima et al., 2011) and applied to maxillofacial surgery (Popowics et al., 2004; Ujigawa et al., 2007; Lima et al.). Currently, the known methods to evaluate the morphological bone adaptation are: the bone displacement direction by photorefractive holographic interferometry (Caroena et al., 2010), stress analysis in photoelastic method (Lima et al.), press transducer (Popowics et al.) and computer simulations using finite element analysis (FEA) (Ujigawa et al.; Ataç et al., 2009; Erkmen et al., 2009).

FEA was applied to study the function of human skull pillars using a two-dimensional (2D) (Hillowalla \& Kanth) and three-dimensional (3D) (Wroe et al.) allowing better

\footnotetext{
" Department of Morphology, Anatomy area, Piracicaba Dental School, State University of Campinas, Piracicaba, São Paulo, Brazil.

** Division of Three-dimensional Technologies, Center for Information Technology "Renato Archer", Campinas, São Paulo, Brazil.

*** Department of Oral Diagnosis, Oral Radiology area, Piracicaba Dental School, State University of Campinas, São Paulo, Brazil.
} 
understanding of force dissipation along the pillar geometry proposed by past studies (Hylander et al.). These studies evaluated the stress distribution from molar occlusion and, thus, with stress sensitivity at zygomatic pillar region.

This study was directed to the CP to discuss the role of biting process in this area and, thus, to relate to different clinical situations that the $\mathrm{CP}$ is involved such as orthodontics and orthognathic surgeries, occlusion correction and rigid fixation in maxillofacial fractures or orthognatic surgery (Manson et al., 1980; Vollmer et al., 1999; Yoshida et al., 2001; Ammar et al., 2011).

Although the several current treatments involving oral rehabilitation have success in dental practice, biomechanical aspects that involve failure cases can be related to inadequate bone tissue response caused by incorrect mechanical induction in the bone geometry. The role of geometry is fundamental to mechanical performance (Wroe et al.). Thus, this study was directed to evaluate the stress distribution along the human CP related to its geometry using FEA with a simulation of peak canine bite in physiological condition.

\section{MATERIAL AND METHOD}

Geometry and Finite element model acquisition. CT images (GE HiSpeed NX/i CT scanner - General Electric, Denver, CO, USA) of a human skull were used to construct a 3D virtual stereolithografic model (STL) (figure 1B) with bone and teeth structures using the InVesalius 3.0b software (Fig. 1A) (Center for Information Technology "Renato Archer", Campinas, Brazil). This study was approved by local Committee on Ethics in Human Research (171/2009).

The STL was transferred to the software Rhinoceros 5.0 (McNeel \& Associates, USA) for geometry acquisition, where the STL model was converted into 3D CAD model (Fig. 1B). The geometry was imported into FEA program ANSYS v14 (Ansys, Inc., USA) for construction of 3D finite element model (FEM). The FEM was composed by 62774 tetrahedral elements and 113180 nodes (Fig. 2).

The structures were considered as linear elastic and isotropic, with elastic modulus and Poisson ratio (14000 MPa
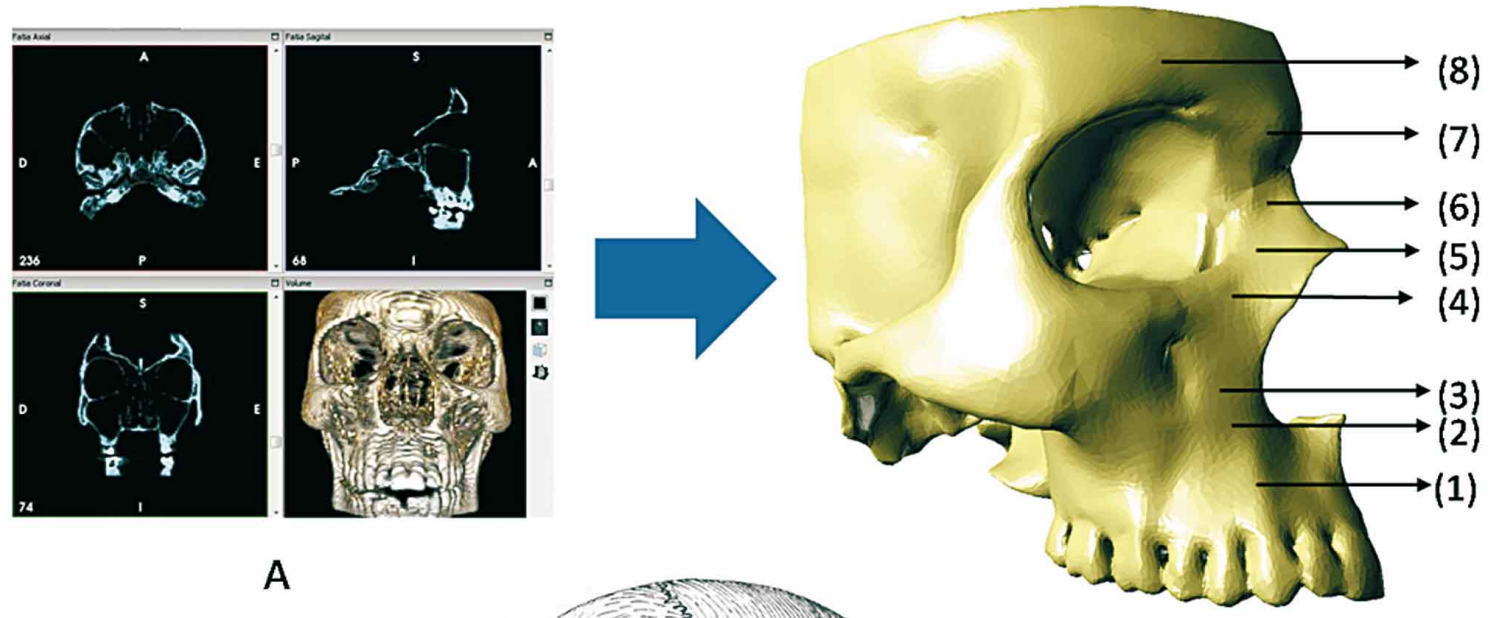

A

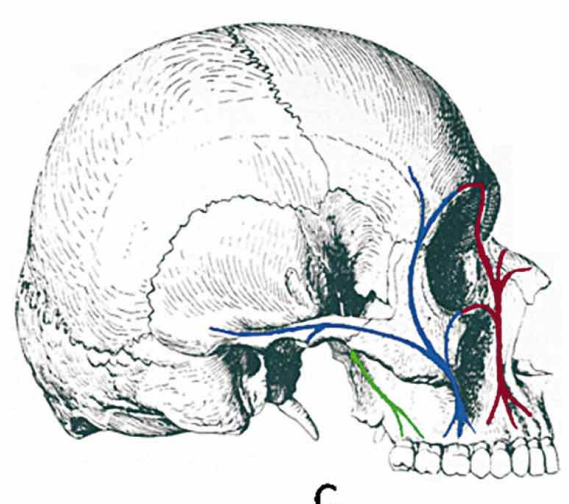

B

C

Fig. 1. Modeling process was directed to build a 3D model of geometry of canine pillar structures. A. Shows the model geometry acquisition from CT images using the InVesalius program. From virtual stereolithographic model (A) was constructed the surfaces that resulted in CAD model (B). C. Shows the load dissipation along the skull pillars from canine bite (red) and molars bite (blue and green). 


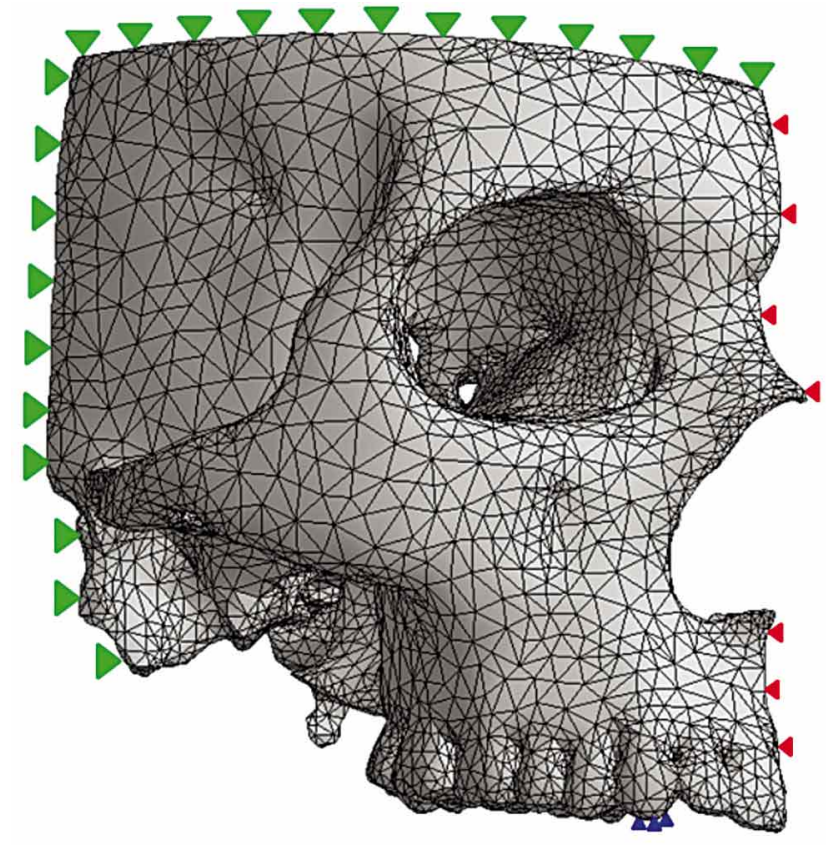

A

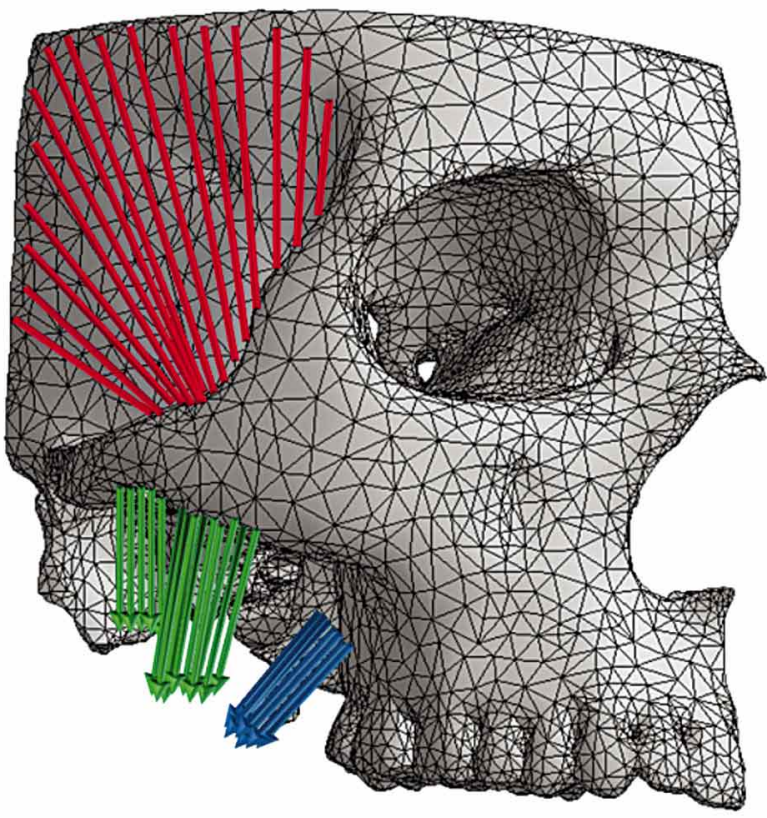

B

Fig. 2. Finite element model composed by tetrahedral mesh (A and B). A. Shows the boundary conditions with application of fixed support (blue), symmetry condition (red) and constraints at the cutting planes (green).

and 0.3 , respectively) for bone applied to the model entirely. This material characterization is defined to study the bone geometrically (Wroe et al.) and, thus, this study was directed to evaluate the stress distribution based on bony geometry of CP.

Boundary conditions and loading. On the medial surface the symmetry condition was applied, simulating the presence of opposite side of skull (Fig. 2A). Constraints were added on superior border at frontal and temporal bones and posterior border at temporal bone (Fig. 2A). At upper canine a fixed support was added on the bite contact (Fig. 2A).

The three masticatory muscles that act during bite (Masseter, Medial pterygoid and Temporal) were simulated (Fig. 2B). The load magnitudes of superficial and deep masseter, medial pterigoid and anterior and middle fibers of temporal muscles (Korioth \& Hannam, 1994; van Essen et $a l ., 2005)$ are present in the Table I.

Stress analysis. The bone structures that compose the CP were analyzed by von-Mises stress (VM) and Maximum principal stress (MP) distribution. MP was used to determine the tensile (positive values) and compressive (negative values) stresses.

Regions were subdivided into segments (Fig. 1B) according force dissipation and $\mathrm{CP}$ constitution: canine
Table I. Load magnitudes of masticatory muscles (N).

\begin{tabular}{lc}
\hline Muscle & Magnitude \\
\hline Superficial masseter & 190.4 \\
Deep masseter & 81.6 \\
Temporal (anterior) & 158 \\
Temporal (middle) & 95.6 \\
Medial Pterygoid & 174.8 \\
\hline
\end{tabular}

eminence (region 1), canine fossa (regions 2 and 3), frontal process of maxilla (regions 4, 5 and 6), glabellum (region 7) and superciliary arch (region 8).

\section{RESULTS}

All stress values according to regions are included in the Table II. From VM analysis a non-uniform stress distribution was observed and represented the force dissipation from the canine tooth toward CP structures. The high stresses occurred at the canine fossa (region 2 and 3) and frontal process of the maxilla (region 5) (Fig. 3). Low stress areas occurred at the canine eminence (region 1), glabellum (region 7) and superciliary arch (region 8) (Fig. $3)$. 
MP analysis presented tensile and compressive stress in the CP structures. Canine eminence, glabellum and superciliary arch presented only tensile stress, while canine fossa and frontal process of maxilla presented both stress types (Fig. 4). MP stresses occurred across the alveolar bone with low intensity at the canine eminence (region 1) and canine eminence (region 3) compared to the high tensile stress areas at the frontal process of maxilla (region 4), glabellum (region 7) and superciliary arch (region 8) (Fig. 4). At the regions 2, 3, 5 and 6 compression occurred, where the high compressive stress located at canine fossa (region 2) and frontal process of maxilla (region 5) (Fig. 4).
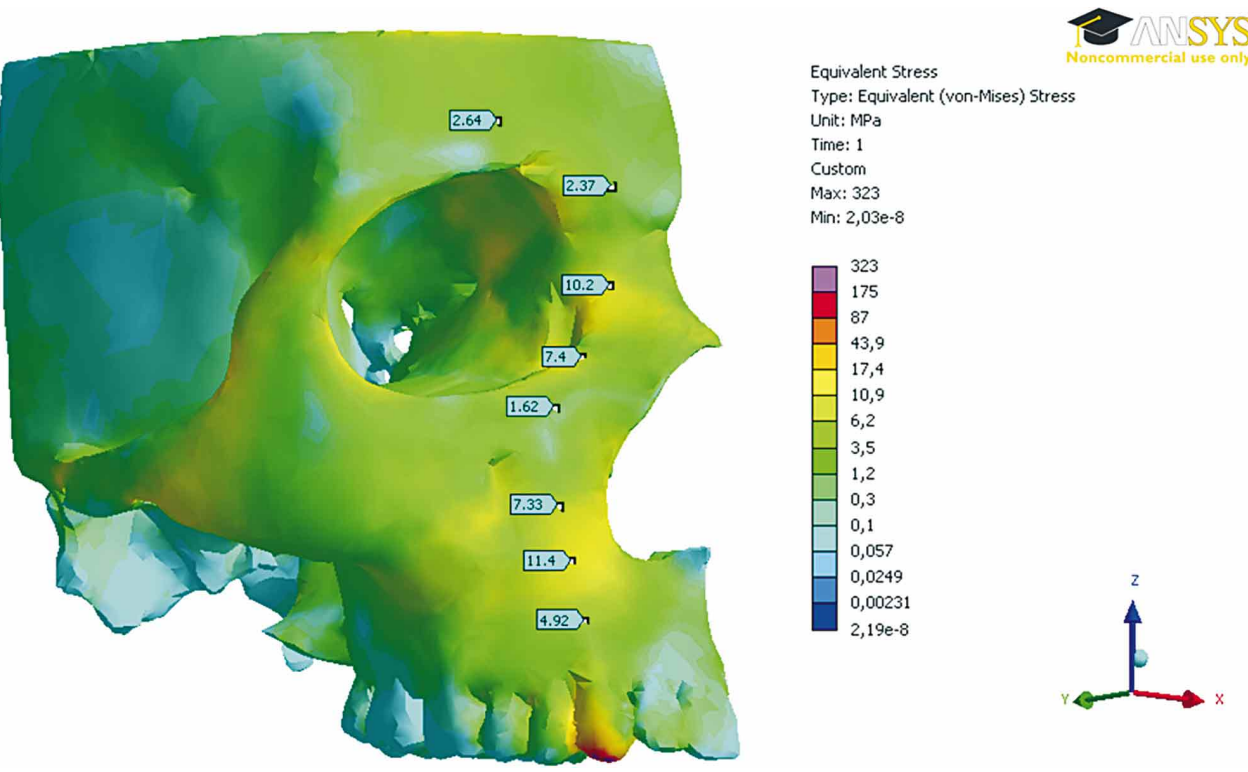

Fig. 3. Equivalent von-Mises stress shows the stress distribution from peak canine tooth bite. The color scale shows the high stress areas by yellow colors and low stress areas by light blue and dark blue colors along the $\mathrm{CP}$ geometry. The regions considered in this study were labeled with the stress values.
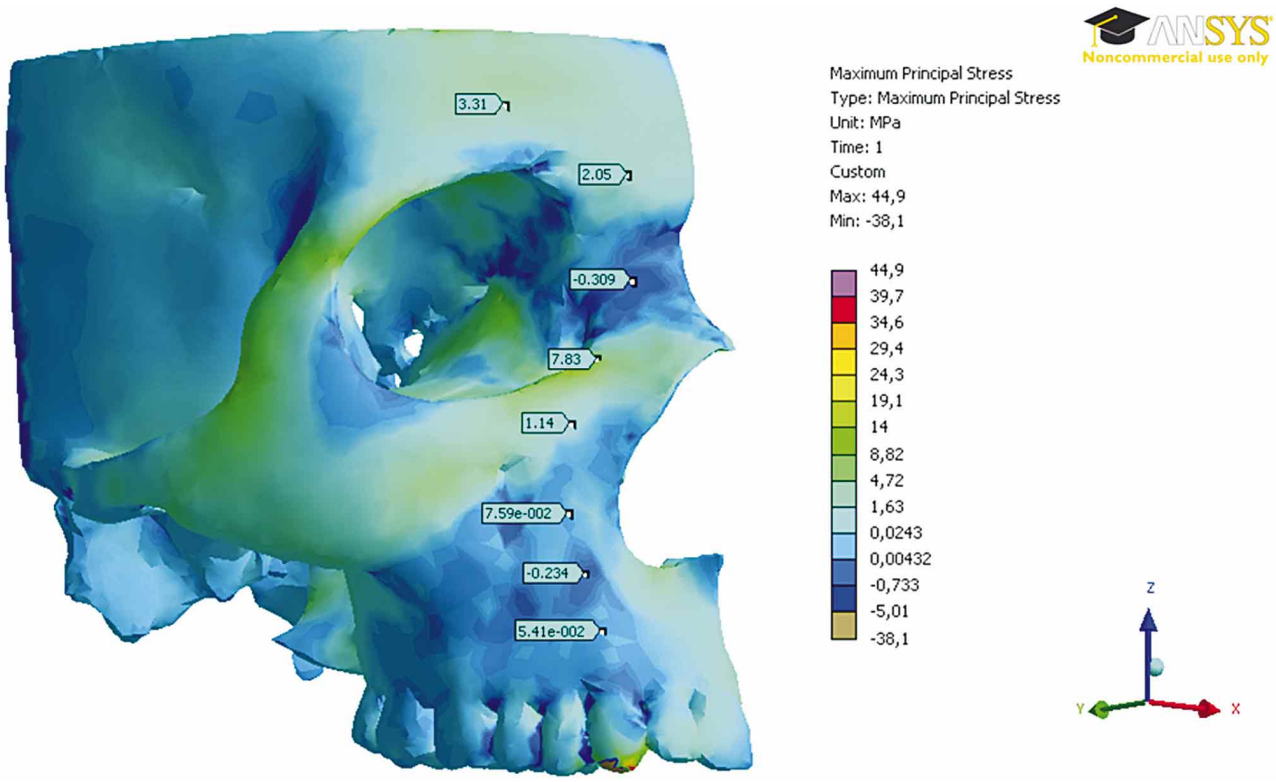

Fig. 4. Maximum principal stress shows the tensile and compressive stress distribution. The color scale shows the high tensile stress areas by green colors and low tensile stress areas by light blue. Dark blue color shows the compressive stress areas. The regions considered in this study were labeled with the stress values. The positive values indicate tensile stress and negative values compressive stress. 
Table II. Stress values (MPa) according the regions of structures that compose the canine pillar.

\begin{tabular}{lcc}
\hline Region & $\begin{array}{c}\text { Equivalent } \\
\text { von-Mises stress }\end{array}$ & $\begin{array}{c}\text { Maximum } \\
\text { principal stress }\end{array}$ \\
\hline 1 & 4.92 & 0.054 \\
2 & 11.4 & -0.234 \\
3 & 7.33 & 0.0759 \\
4 & 1.62 & 1.14 \\
5 & 7.4 & 7.83 \\
6 & 10.2 & -0.309 \\
7 & 2.37 & 2.05 \\
8 & 2.64 & 3.31 \\
\hline
\end{tabular}

\section{DISCUSSION}

Bone geometry of skull pillars have been associated to configurations of masticatory loads dissipation. This configuration involves both the bone type (cortical or cancellous) and the geometry of each isolated bone structure of the pillars. Cortical bone thickness and density in human maxilla, involving the canine pillar, were evaluated by Peterson et al. (2006), and these authors verified that areas with minor thickness have major density. Those authors observed at the $\mathrm{CP}$ region that the canine fossa presented the average thickness $1,7 \pm 0,7 \mathrm{~mm}$ and density $1,69 \pm 0,15$ $\mathrm{mg} / \mathrm{cm}^{3}$. In this context, the analysis of VM stress in our study presented low stress concentration at this region. Thus, although our study has evaluated the bone geometry, it suggests that to the low stress concentration occurred due to

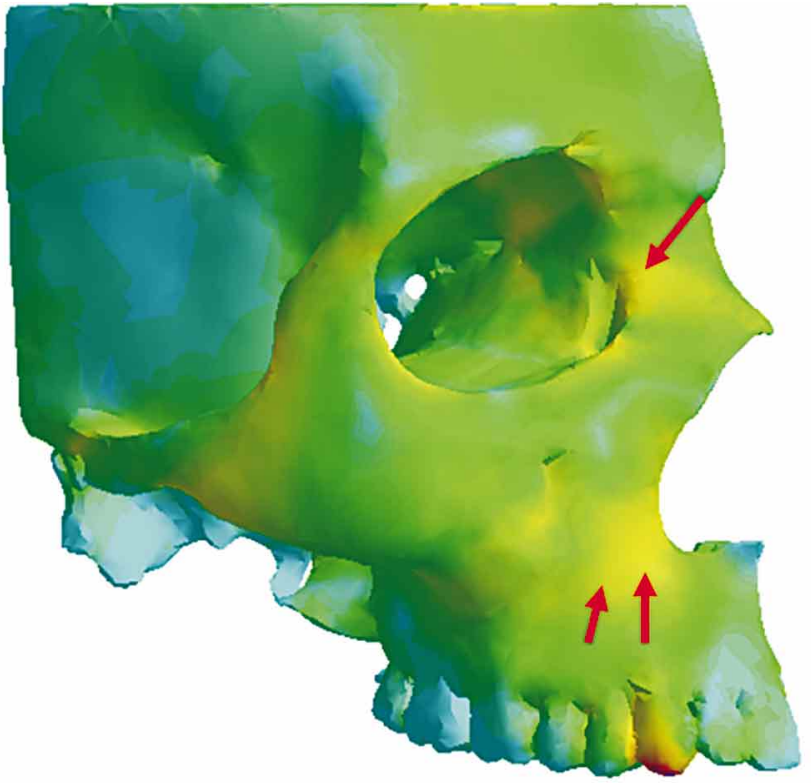

the minor average density of cortical bone. While at the frontal process of the maxilla, which cortical bone quantity is major (average density $1,83 \pm 0,17 \mathrm{mg} / \mathrm{cm}^{3}$ ), high concentration of VM stress was verified. Thus, from the concept that in the predominance of cortical bone the loads are better absorbed than transmitted, at the regions of $\mathrm{CP}$ with high VM stress concentration (region 5) the functional loads were absorbed (Peterson et al., 2006).

Although the analysis has expressed the VM and MP stress values, this study did not intend to determine absolute stress magnitudes, but assisted in the localization of high and low stress distribution based on CP geometry. The role of geometry is fundamental to mechanical performance (Wroe et al.). This condition is also conformed due to variations in mechanical properties applied to the bone and it is known that differences in the distribution of materials can influence the results (Strait et al., 2005). Thus, high VM stress regions were localized at the frontal process of maxilla, which more likely was due to its geometry. In addition, the stress results can be more localized due to excessive bone rigidity, as occurs from material data of dried skull, i.e., only inorganic bone. However, on fresh bone in vivo, Caroena et $a l$. presumed that the deformations values can result two or three times greater than on the dried skull.

Ross (2001) reported that the geometry of structures located at the anterior region in the skull of primates have a great importance in the axial loads, resulting in a compressive stress mainly at the frontal process of maxilla. Similarly in our study we observed this type of stress at this region (Fig. 4).

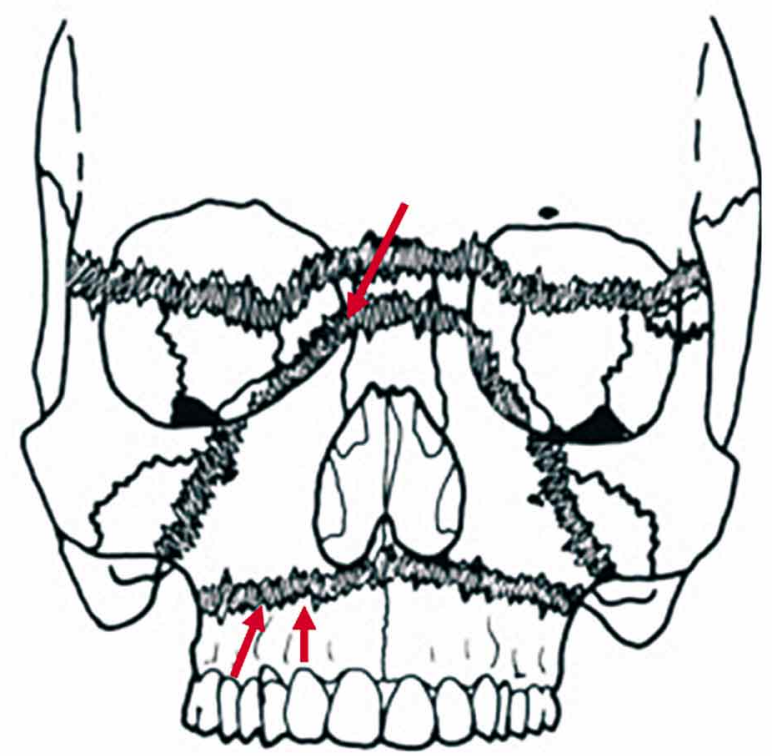

Fig. 5. VM stress showed stress areas distributed at similar regions of Le Fort facial fractures. The regions are marked by arrows showing the stress concentration (A) related, mainly, to the common Le Fort I and III fractures patterns (B). 
The upper canine tooth has a particular function as disocclusion guide during chewing. The canine guide has a better adaptation to excursive forces because the canine tooth root has a longer and larger diameter. The peridental bone tissue is dense and massive due to high tolerance by the canine eminence under masticatory forces (D'Amico, 1961). This study showed low VM stress at this region under occlusion peak. However, analysis of a lateral movement of mandible also could be performed to simulate the excursive forces and allow detailed tolerance of canine eminence under these circumstances. In addition, the observation of MP stress showed low tensile stress at the canine eminence and, thus, we can suggest that the canine eminence geometry is adapted to support low force concentration. In pathologic conditions caused by malocclusions this may result in increased force, whose effect is related to probability of a dehiscence occurring at this region compared to lateral and central incisors (Aksoy et al., 2002).

$\mathrm{CP}$ is a supporting structure for dissipation of mechanical forces from masticatory origin, being less resistant to horizontal forces, such as the fractures involving the midface that affect different areas of the skull pillars (Le Fort I, II and III fractures) (Misch \& Bidez, 1994) (Fig. 5). From this condition, it was suggested that is essential to start the face rebuilding by primary support pillars, as the $\mathrm{CP}$ (Manson et al.), due to the relation to the mechanical dissipation of dynamic actions, such as chewing, in these areas. Our results showed the concentrated VM stresses at the areas affected by these fractures (Fig. 5). Moreover, this stress is related to compressive stress (Fig. 4). Thus, these FEA results contribute for using the specific areas of the CP as reference for face rebuilding considering the local and characteristics of the materials used in internal rigid fixation.

The maxillary bone is relatively weak, susceptible to atrophy and structural failure when exposed to metabolic and/or adverse mechanical demands. Furthermore, the understanding of the occlusal forces dissipation along the pillars of the skull can support the diagnosis of masticatory changes in oral rehabilitation planning, in the stress distribution by teeth and implants and craniofacial bone remodeling (Hylander et al.).

Within the limitations in FEA, the results showed that the different stress areas presented at different locations means different force concentrations transmitted along the $\mathrm{CP}$ geometry during a peak canine bite. This data contributes to the force dissipation idea (Hylander et al.; Hillowalla \& Kanth; Caroena et al.).

\section{CONCLUSION}

The areas with high stress were related to complex bone geometry involving depth surface region (canine fossa) and bone projection (frontal process of maxilla). MP stress showed that the CP geometry have sensibility for compressive and tensile stress. In general, the canine fossa, which is located in maxillary body region, and the frontal process supported the idea that these bones have geometries adapted for compressive stress.

\section{ACKNOWLEDGEMENTS}

The authors are thanks to Coordination for the Improvement of Higher Level -or Education- Personnel (CAPES), Brazil for financial support and the Center for Information Technology "Renato Archer" (Campinas, Brazil) for technical and scientific support.

FREIRE, A. R.; PRADO, F. B.; ROSSI, A. C.; NORITOMI, P. Y.; NETO, F. H. \& CARIA, P. H. F. Biomecánica del pilar canino en el cráneo humano basada en la geometría utilizando análisis de elementos finitos. Int. J. Morphol., 32(1):214-220, 2014.

RESUMEN: Este estudio evaluó la distribución de la tensión sobre la geometría del pilar canino en el cráneo humano, utilizando análisis de elementos finitos. Se usó la tomografía computarizada de cráneo humano para construir un modelo de elementos finitos compuesto por todas las estructuras óseas del pilar canino: eminencia canina, fosa canina, proceso frontal del maxilar, glabela y arco superciliar. Se aplicó en la simulación un soporte ubicado sobre el contacto de mordida del diente canino maxilar y una fuerza resultante de los músculos de la masticación. Tensiones Equivalentes de Von-Mises y tensiones principales máximas fueron analizadas a lo largo de las estructuras que componen la geometría de pilar canino. La tensión de Von-Mises fue alta y concentrada en la fosa canina y proceso frontal del maxilar. La tensión principal máxima mostró áreas de compresión en la fosa canina y parte del proceso frontal y la tensión de tracción en la eminencia canina y parte del proceso frontal. Las diferentes áreas de tensión significan diferentes concentraciones de tensiones transmitida a lo largo de la geometría del pilar canino durante una mordedura canina máxima.

PALABRAS CLAVE: Cráneo; Biomecánica; Análisis de elementos finitos. 


\section{REFERENCES}

Aksoy, E.; Unlu, E.; \& Sensoz, O. A retrospective study on epidemiology and treatment of maxillofacial fractures. $J$. Craniofac. Surg., 13(6):772-5, 2002.

Ammar, H. H.; Ngan, P.; Crout, R. J.; Mucino, V. H.; \& Mukdadid, O. M. Three-dimensional modeling and finite element analysis in treatment planning for orthodontic tooth movement. Am. J. Orthod. Dentofacial Orthop., 139(1):e59-71, 2011.

Ataç, M. S.; Erkmen, E.; Yücel, E. \& Kurt, A. Comparison of biomechanical behaviour of maxilla following Le Fort I osteotomy with 2- versus 4-plate fixation using 3D-FEA Part 2: impaction surgery. Int. J. Oral Maxillofac. Surg., 38(1):5863, 2009.

Caroena, G.; Mori, M.; Gesualdi, M. R.; Liberti, E. A.; Ferrara, E. \& Muramatsu M. Mastication effort study using photorefractive holographic interferometry technique. J. Biomech., 43(4):6806, 2010.

D'Amico, A. Functional occlusion of the natural teeth of man. $J$. Prosthet. Dent., 11(5):899-915, 1961.

Erkmen, E.; Ataç, M. S.; Yücel, E. \& Kurt, A. Comparison of biomechanical behaviour of maxilla following Le Fort, I. osteotomy with 2- versus 4-plate fixation using 3D-FEA: part 3: inferior and anterior repositioning surgery. Int. J. Oral Maxillofac. Surg., 38(2):173-9, 2009.

Fanuscu, M. I. \& Caputo, A. A. Influence of attachment systems on load transfer of an implant-assisted maxillary overdenture. J. Prosthodont., 13(4):214-20, 2004.

Hilloowala, R. \& Kanth, H. The transmission of masticatory forces and nasal septum: structural comparison of the human skull and Gothic cathedral. Cranio, 25(3):166-71, 2007.

Hylander, W. L.; Picq, P. G. \& Johnson, K. Masticatory-stress hypotheses and the supraorbital region of primates. Am. J. Phys. Anthropol., 86(1):1-36, 1991.

Korioth, T. W. \& Hannam, A. G. Deformation of the human mandible during simulated tooth clenching. J. Dent. Res., 73(1):56-66, 1994.

Lima, S. M. Jr.; de Moraes, M. \& Asprino, L. Photoelastic analysis of stress distribution of surgically assisted rapid maxillary expansion with and without separation of the pterygomaxillary suture. J. Oral Maxillofac. Surg., 69(6):1771-5, 2011.

Manson, P. M.; Hoopes, J. E. \& Su, C. T. Structural pillars of the facial skeleton: an approach to the management of Le Fort fractures. Plast. Reconst. Surg., 66(1):54-62, 1980.

Misch, C. E. \& Bidez, M. W. Implant-protected occlusion: a biomechanical rationale. Compendium, 15(11):1330-44, 1994.
Peterson, J.; Wang, Q. \& Dechow, P. C. Material properties of the dentate maxilla. Anat. Rec. A Discov. Mol. Cell. Evol. Biol., 288(9):962-72, 2006.

Popowics, T. E.; Rensberger, J. M. \& Herring, S. W. Enamel microstructure and microstrain in the fracture of human and pig molar cusps. Arch. Oral Biol., 49(8):595-605, 2004.

Ross, C. F. In vivo function of the craniofacial haft: the interorbital "pillar". Am. J. Phys. Anthropol., 116(2):108-39, 2001.

Sorní, M.; Guarinos, J. \& Peñarrocha, M. Implants in anatomical buttresses of the upper jaw. Med. Oral Patol. Oral Cir. Bucal, 10(2):163-8, 2005.

Strait, D. S.; Wang, Q.; Dechow, P. C.; Ross, C. F.; Richmond, B. G.; Spencer, M. A. \& Patel, B. A. Modeling elastic properties in finite-element analysis: how much precision is needed to produce an accurate model? Anat. Rec. A Discov. Mol. Cell. Evol. Biol., 283(2):275-87, 2005.

Ujigawa, K.; Kato, Y.; Kizu, Y.; Tonogi, M. \& Yamane, G. Y. Threedimensional finite elemental analysis of zygomatic implants in craniofacial structures. Int. J. Oral Maxillofac. Surg., 36(7):620-5, 2007.

van Essen, N. L.; Anderson, I. A.; Hunter, P. J.; Carman, J.; Clarke, R. D. \& Pullan, A. J. Anatomically based modelling of the human skull and jaw. Cells Tissues Organs, 180(1):44-53, 2005.

Vollmer, D.; Bourauel, C.; Maier, K. \& Jäger, A. Determination of the centre of resistance in an upper human canine and idealized tooth model. Euro. J. Orthod., 21(6):633-48, 1999.

Wroe, S.; Ferrara, S. T.; McHenry, C. R.; Curnoe, D. \& Chamoli, U. The craniomandibular mechanics of being human. Proc. Biol. Sci., 277(1700):3579-86, 2010.

Yoshida, N.; Koga, Y.; Mimaki, N. \& Kobayashi, K. In vivo determination of the centers of resistance of maxillary anterior teeth subjected to retraction forces. Eur. J. Orthod., 23(5):529-34, 2001.

Correspondence to:

Alexandre Rodrigues Freire

Department of Morphology

Piracicaba Dental School, P.O. Box 52

University of Campinas - UNICAMP

13414-903, Piracicaba, SP

BRAZIL

Email: alerfreire@gmail.com

Received: 20-08-2013

Accepted: 19-11-2013 